\title{
PENGEMBANGAN MEDIA PEMBELAJARAN KOMIK BERBASIS APLIKASI ANDROID PADA MATERI SISTEM PERSAMAAN LINEAR DUA VARIABEL
}

\author{
Noor Mayaminiy Maulidah \\ Pendidikan Matematika, STKIP PGRI Sidoarjo \\ miniymaya@gmail.com \\ Achmad Dhany Fachrudin \\ Pendidikan Matematika, STKIP PGRI Sidoarjo \\ Lailatul Mubarokah \\ Pendidikan Matematika, STKIP PGRI Sidoarjo
}

\begin{abstract}
Abstrak
Pengembangan media pembelajaran komik berbasis android dilatarbelakangi dengan banyaknya siswa yang sulit dalam mencapai ketuntasan belajar pada materi Sistem Persamaan Linear Dua Variabel (SPLDV). Diketahui berdasarkan analisis lapangan, salah satu penyebabnya adalah banyak waktu yang terbuang untuk memahami soal, membuat model matematika dan penyelesaiannya. Tujuan dari penelitian yaitu mengembangkan media pembelajaran yang menarik, mudah digunakan dan bisa meningkatkan hasil belajar siswa terutama kelas VIII. Karena banyak orang yang sudah menggunakan android seiring semakin berkembangnya teknologi, maka media pembelajaran yang dikembangkan berbasis android. Hal ini juga mendukung pelaksanaan Pembelajaran Jarak Jauh (PJJ) selama pandemi. Konsep media pembelajaran yaitu penyampaian materi dalam bentuk komik yang disesuaikan dengan urutan penyelesaian tiap langkah. Penelitian ini ditujukan pada siswa kelas VIII. Penelitian ini menggunakan 10 tahapan model pengembangan menurut Sugiyono tahun 2012. Dan untuk kriteria kualitas media pembelajaran menggunakan tiga kriteria menurut Nieveen tahun 1999. Penyajian dan kesesuaian antara materi dan media dinilai sangat valid dengan skor rata-rata 3,43. Kepraktisan bernilai sangat praktis sehingga mudah digunakan oleh siswa dan guru dengan skor ratarata 3,42. Berdasarkan hasil belajar diperoleh bahwa media bernilai efektif digunakan oleh siswa dengan skor rata-rata respons siswa 3,17, dan skor rata-rata tes hasil belajar siswa 74,7, dengan KKM 70. Jadi dapat disimpulkan media pembelajaran yang dikembangkan memenuhi kriteria.
\end{abstract}

Kata Kunci: Media Pembelajaran, Komik, Android, SPLDV

\footnotetext{
Abstract

The development of android-based comical learning media is motivated by the number of students who find it difficult to achieve complete learning on the
} 
material for the Two Variable Linear Equation System (SPLDV). It is known that based on the field analysis, one of the reasons is that a lot of time is wasted to understanding the problem, making mathematical models and than solving them. The purpose of this research is to develop learning media that is attractive, easy to use and can improve the students learning outcomes, especially in class grade eight. Because many students are already using Android as technology develops, the teaching media developed is based on Android. It also supports the implementation of Distance Learning (PJJ) during the pandemic. The concept of learning media is the delivery of material in the form of comics that are adjusted to the order of completion of each step. This research is aimed at eighth grade students. This research used 10 stages of the development model, according to Sugiyono (2012). And for the criteria for the quality of learning media using three criteria according to Nieveen (1999). The presentation and suitability between the material and the media is considered with validity with an average score of 3.43. it is very practical, so it is easy to use by students and teachers with an average score of 3.42. Based on the results of the study, it was found that the effective value media was used by students with an average score of 3.17 student responses, and an average score of 74.7 student learning outcomes tests, with a KKM of 70. So it can be deduced that the learning media developed fulfills the criteria.

\section{Keywords: Learning Media, Comics, Android, SPLDV}

\section{PENDAHULUAN}

Hasil observasi di SMP Negeri 1 Candi Sidoarjo kelas VIII pada 16 Oktober 2020 menunjukkan bahwa 65\% siswa kelas VIII di SMP Negeri 1 Candi mengalami kesulitan menyelesaikan soal matematika yang berhubungan dengan soal cerita. Menurut Tumardi (dalam Hidayah, 2016) soal cerita merupakan pokok bahasan yang sulit dikuasai oleh siswa, tidak hanya siswa di Indonesia namun juga siswa di negara-negara lain. Hal tersebut dapat ditinjau dari kesalahankesalahan yang dilakukan siswa dalam menyelesaikan soal cerita yang diberikan. Pada materi yang menggunakan soal cerita, siswa membutuhkan pemahaman lebih supaya bisa memahami masalah yang ada, mengubah pemahaaman tersebut ke model matematika dan menyelesaikan masalah sesuai dengan langkah penyelesaian. Tahapan tersebut adalah langkah penyelesaian masalah Polya (1973). Salah satu materi pada kelas
VIII yang mempelajari terkait soal cerita adalah materi sistem persamaan linear dua variabel (SPLDV). Oleh sebab itu, diperlukan strategi khusus untuk memecahkan masalah soal cerita pada materi SPLDV salah satunya yaitu dengan menggunakan media pembelajaran.

Pembelajaran dengan memaanfaatkan media pembelajaran, diharapkan dapat memudahkan guru dan siswa dalam melaksanakan pembelajaran. Media pembelajaran adalah alat bantu pada proses belajar di dalam maupun di luar kelas yang dapat merangsang siswa untuk belajar (Arsyad, 2011). Kenyataannya guru SMP Negeri 1 Candi Sidoarjo mengalami kendala dan kerepotan untuk menyiapkan media pembelajaran, dengan kata lain pembelajaran yang dilakukan hanya sebatas pembelajaran konvensional. Oleh sebab itu, peneliti mengembangkan media pembelajaran untuk memudahkan guru dalam menyampaikan materi dan siswa mudah memahami apa yang disampaikan oleh guru. 
Teknologi digunakan sebagai media pembelajaran inovatif diyakini mampu mengikuti perkembangan zaman. Menurut Sakat (dalam Lubbis, 2015) pembelajaran yang menggunakan media teknologi memberikan pengaruh yang signifikan terhadap pembelajaran. Contoh dari penelitian mengembangkan media pembelajaran yang sudah ada yaitu dilakukan oleh Wafiyah dan Wintarti (2019), Budiarti dan Haryanto (2016). Hasilnya yaitu media pembelajaran yang dibuat bisa memenuhi kriteria pada pembelajaran sehingga dapat membantu memudahkan siswa dalam belajar dan meningkatkan hasil belajar siswa.

Perangkat smartphone sangat dekat dengan kehidupan siswa saat ini. Selain sebagai fungsi komunikasi, perangkat smartphone juga sangat berpotensi dikembangkan menjadi media pembelajaran interaktif yang bermanfaat bagi siswa. Pada kondisi saat ini, sangat memungkinkan melakukan Pendidikan Jarak Jauh (PJJ) yaitu mengajarkan siswa belajar terpisah dari guru dan pembelajarannya menggunakan sumber belajar internet atau online sesuai teknologi informasi dan komunikasi dengan bantuan media yang canggih.

Pada umumnya smartphone merupakan perangkat yang dijalankan oleh sistem operasi android. Menurut Holla dan Katti (2012) Aplikasi android adalah platform penting untuk mengembangkan aplikasi mobile menggunakan software stack yang disediakan di google Android SDK. Salah satu software yang dapat digunakan untuk membuat media pembelajaran yaitu Unity 3D. Menurut Iqbal (2003:5), komik metematika adalah komik yang secara implisit memuat konsep-konsep atau persoalan matematika.

Metode yang digunakan untuk penelitian ini adalah sepuluh tahapan model pengembangan menurut Sugiyono (2012), yaitu: Potensi dan Masalah; Pengumpulan Data; Desain Produk; Validasi Desain; Revisi Desain; Uji Coba Produk; Revisi Produk; Uji Coba Pemakaian; Revisi Produk; Produksi. Teknik analisis data juga dibutuhkan untuk mengetahui kriteria produk pengembangan pada penelitain ini menggunakan menurut Nieveen (1999) yaitu harus memenuhi kriteria valid, praktis dan efektif.

Berdasarkan dari permasalahan di atas maka penelitian yang akan dilakukan adalah "Pengembangan Media Pembelajaran Komik Berbasis Aplikasi Android pada Materi Sistem Persamaan Linear Dua Variabel (SPLDV) Kelas VIII". Cara penyampaian materi SPLDV yang akan dibuat yaitu dengan komik. Komik yang akan dibuat menjelaskan secara prosedural pengerjaan dalam menyelesaikan soal SPLDV.

\section{METODE}

Metode penelitian ini menggunakan 10 tahap pengembangan menurut Sugiyono (2012) dengan kriteria pengembangan media pembelajaran menurut Nieveen (1999). Tahap model pengembangan yang di adaptasi dari Sugiyono (2012) seperti pada gambar di bawah ini: 


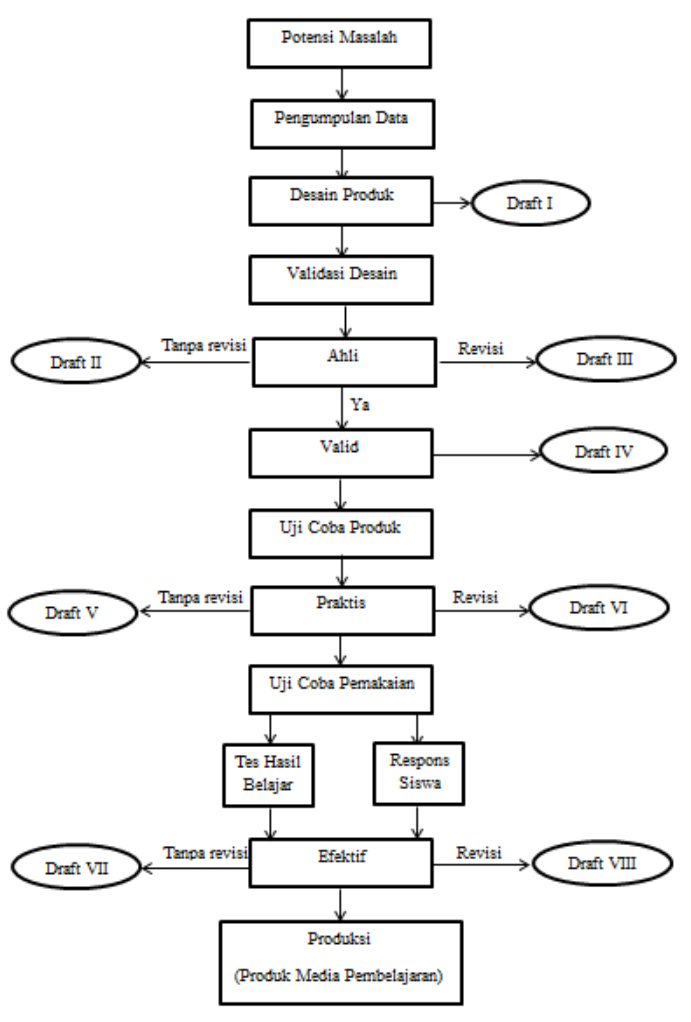

Gambar 1. Tahap Model Pengembangan (Adaptasi dari Sugiyono, 2012)

Kriteria penilaian yang digunakan pada penelitian ini adalah kevalidan, kepraktisan dan keefektifan. Kevalidan mengacu pada penyajian materi dan kesesuaian antar materi dan media. Keprkatisan mengacu pada kepraktisan media yang mudah digunakan oleh guru dan siswa seperti yang diharapkan. Keefektifan mengacu pada meningkatnya pemahaman siswa dan hasil belajar siswa setelah menggunakan media.

Teknik pengumpulan data yang digunakan pada penelitian ini yaitu wawancara, angket, tes hasil belajar dan dokumentasi. Instrumen yang digunakan pada penelitian ini adalah lembar angket validasi ahli, lembar angket praktisi dan lembar angket respons siswa.

\section{HASIL DAN PEMBAHASAN}

\section{Potensi dan Masalah}

Dengan mempelajari materi SPLDV yang dihubungkan dengan kehidupan sehari-hari dapat dijadikan potensi karena siswa bisa dengan mudah menerapkan materi SPLDV pada kehidupan seharihari. Sedangkan kesalahan dalam menyelesaikan materi SPLDV dapat dijadikan masalah. Masalah ini dapat diatasi melalui model atau media pembelajaran interaktif.

\section{Pengumpulan Data}

\section{a. Wawancara}

Hasil wawancara yang dilakukan kepada guru matematika dan siswa kelas VIII SMP Negeri 1 Candi pada tanggal 16 Oktober 2020. Pada hasil wawancara guru menunjukkan $65 \%$ siswa kelas VIII di SMP Negeri 1 Candi mengalami kesulitan menyelesaikan soal cerita. Sehingga, guru membutuhkan salah satu alternatif media pembelajaran yang mudah diakses oleh siswa pada pandemi saat ini dan bisa meningkatkan hasil belajar siswa. Hasil wawancara siswa kelas VIII menunjukkan siswa sulit memahami dan menyelesaikan soal cerita terutama pada pandemi saat ini. Karena mengharuskan siswa lebih banyak waktu belajar sendiri dan tidak bisa tanya langsung ke guru jika kesulitan.

Berdasarkan hasil wawancara tersebut dapat disimpulkan bahwa dalam proses pembelajaran diperlukan media pembelajaran yang bisa membantu siswa dan guru dalam pembelajaran. Media pembelajaran yang diharapkan juga bisa dengan mudah diakses dimanapun dan kapanpun terutama pada kondisi pandemi saat ini. 


\section{b. Studi Literatur}

Berdasarkan studi literatur, media pembelajaran yang dibutuhkan oleh siswa dan guru pada masa pandemi adalah media pembelajaran yang berbasis android. Salah satu alternatif media pembelajaran berbasis android yang bisa digunakan adalah media pembelajaran komik dikarenakan komik lebih menarik dan mudah dipahami karena terdapat interaksi antar tokoh dalam cerita komik tersebut. Jadi peneliti, mengembangkan media pembelajaran komik berbasis android.

\section{Desain Produk}

a. Judul aplikasi media pembelajaran yaitu KODIM (Komik Digital Matematika).

b. Indikator yang akan dicapai setelah mempelajari media yaitu:

o Menganalisis soal cerita dari masalah sehari-hari berkaitan dengan Sistem Persamaan Linear Dua Variabel (SPLDV).

o Membuat model matematika dari masalah sehari-hari berkaitan dengan Sistem Persamaan Linear Dua Variabel (SPLDV).

o Menyelesaikan soal cerita dari masalah sehari-hari berkaitan dengan Sistem Persamaan Linear Dua Variabel (SPLDV).

c. Tujuan dari media yaitu siswa mudah memahami dan menyelesaikan permasalahan materi SPLDV yang berkaitan dengan sehari-hari.

d. Karakter komik yang digunakan dalam media pembelajaran yaitu Doraemon dan teman-teman karena Doraemon merupakan salah satu kartun favorit dan banyak disukai segala usia.

e. Materi terdiri dari 2 subbab pemahaman konsep sebelum mempelajari SPLDV dan 3 subbab metode penyelesaian SPLDV yaitu eliminasi, substitusi, dan campuran.

f. Rancangan media pembelajaran komik berbasis android merupakan alur media pembelajaran komik berbasis android yang dapat dilihat pada gambar 3 di bawah ini:

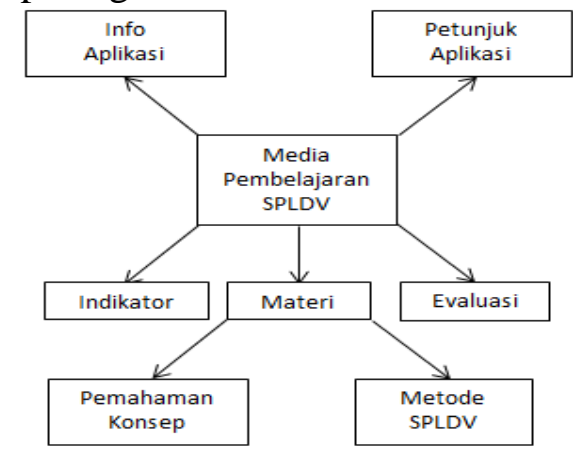

Gambar 2. Rancangan Media Pembelajaran

g. Tampilan aplikasi
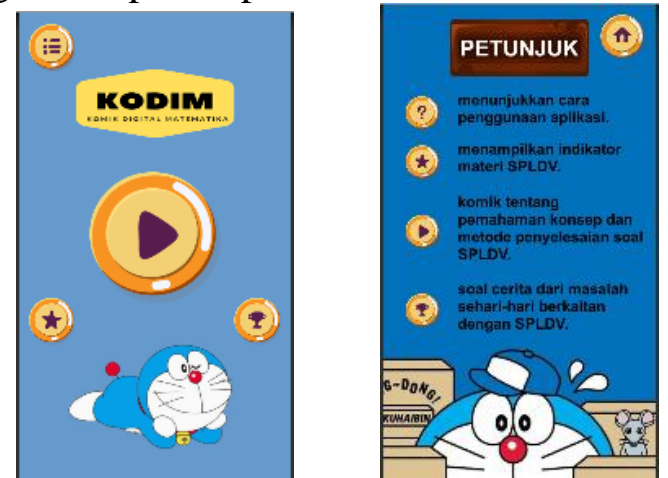

Gambar 3. Tampilan Halaman Menu dan Petunjuk Penggunaan Aplikasi
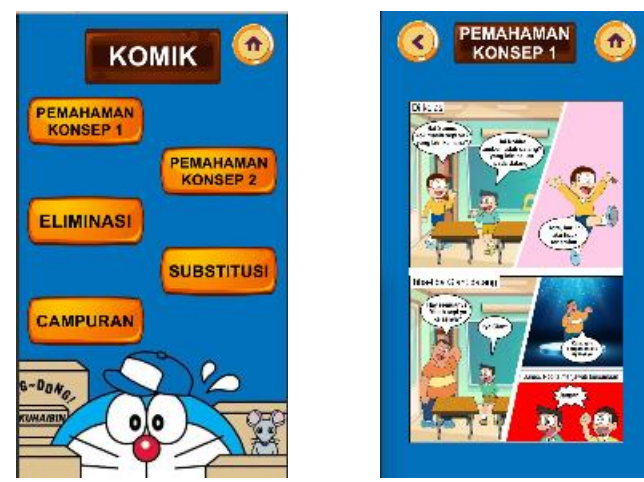

Gambar 4. Tampilan Halaman Menu Materi Komik dan Halaman Komik 


\section{Validasi Desain}

Validasi desain media diuji oleh 2 pakar media pembelajaran yang juga merupakan pakar materi SPLDV dengan hasil skor rata-rata 3,43, termasuk dalam kategori sangat valid dengan tambahan saran yaitu:

a. Menambahkan tombol keluar di halaman depan.

b. Menyamakan nominal uang yang dikasih ibu Nobita pada Nobita dan Doraemon pada komik subbab substitusi.

c. Mengganti beberapa kata ambigu pada komik subbab campuran.

d. Mencari alternatif seperti memecah media menjadi 2 supaya file media tidak terlalu besar.

Maka dapat disimpulkan media memenuhi salah satu kategori penilaian menurut Nieveen (1999).

\section{Revisi Desain}

Berdasarkan penilaian pakar media dan materi, maka media pembelajaran direvisi sesuai saran dari pakar. Berikut adalah hasil revisi sesuai saran dari pakar:

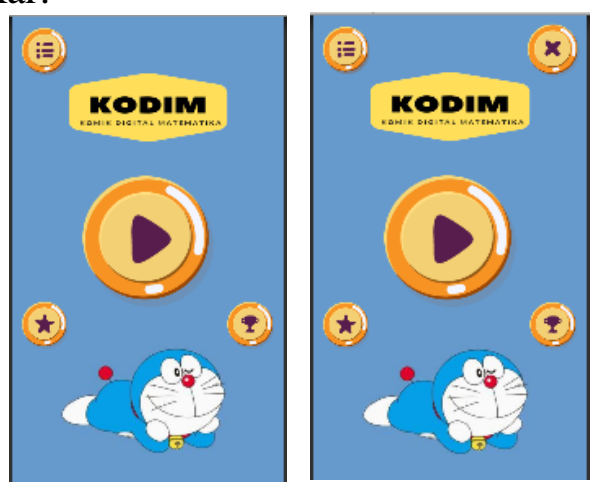

Gambar 5. Tampilan Sebelum dan Sesudah Revisi
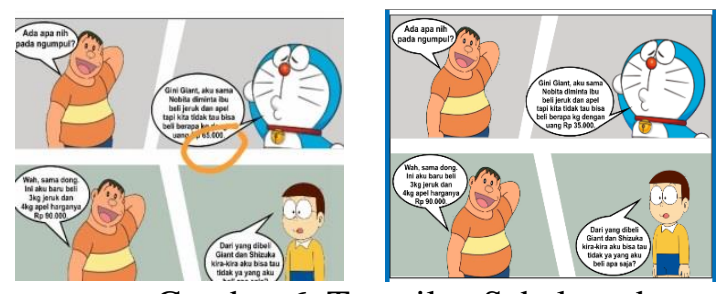

Gambar 6. Tampilan Sebelum dan Sesudah Revisi

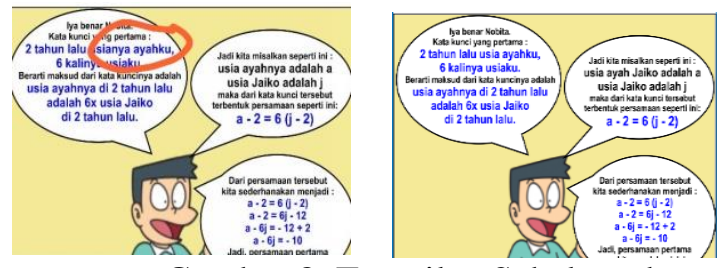

Gambar 8. Tampilan Sebelum dan

Sesudah Revisi

Jika ukuran media dipecah menjadi dua, ukuran file media lebih besar dibandingkan satu media. Maka media tidak dipecah menjadi dua.

\section{Uji Coba Produk}

Setelah melalui tahap validasi dan sudah direvisi berdasarkan masukan dari pakar media dan materi, selanjutnya media pembelajaran diujicobakan kepada praktisi (guru matematika) untuk mengetahui kepraktisan dan keefektifan media bagi guru dan siswa. Hasil praktisi dari guru matematika diperoleh skor dengan rata-rata 3,42 yang termasuk kategori sangat praktis. Maka dapat disimpulkan media memenuhi salah satu kategori penilaian menurut Nieveen (1999).

\section{Revisi Produk}

Berdasarkan hasil praktisi, maka kesimpulannya tidak ada perbaikan pada media pembelajaran dan media pembelajaran layak untuk diujicobakan kepada siswa. 


\section{Uji Coba Pemakaian}

Setelah aplikasi melalui tahap validasi pakar dan diujicobakan ke guru matematika, selanjutnya produk diujicobakan kepada siswa untuk mengetahui kekurangan atau hambatan dari aplikasi. Uji coba dilakukan kepada 35 siswa dengan skor rata-rata hasil respons siswa adalah 3,17, termasuk kategori setuju. Siswa juga memberikan tanggapan kritik dan saran yaitu ukuran aplikasi jika bisa dikecilkan, aplikasi kreatif, menarik, mudah digunakan dan lebih baik diunggah ke play store.

Selain itu, hasil belajar siswa setelah menggunakan media juga meningkat. Dari 35 siswa, 13 siswa mendapatkan nilai di atas KKM, 18 siswa mendapatkan nilai sama dengan KKM, dan 4 siswa mendapatkan nilai di bawah KKM. Sehingga, rata-rata hasil belajar siswa tersebut adalah 74,7, termasuk kategori baik dengan nilai KKM 70. Maka, dapat disimpulkan bahwa media pembelajaran efektif, bisa meningkatkan hasil belajar siswa pada materi SPLDV dan memenuhi salah satu kategori penilaian menurut Nieveen (1999).

\section{Revisi Produk}

Berdasarkan hasil respons siswa dan hasil belajar siswa, maka kesimpulannya tidak ada perbaikan pada media pembelajaran dan media pembelajaran layak untuk diproduksi dan bisa digunakan oleh siapapun.

\section{Produksi}

Setelah divalidasikan kepada pakar dan diujicobakan kepada guru matematika dan siswa, maka media pembelajaran layak untuk diproduksi dan bisa digunakan oleh siapapun.

Cara mengunduh dan menginstall aplikasi media pembelajaran komik berbasis android yaitu:

a. Download aplikasi di link https://bit.ly/KODIMAplikasi

b. Setelah aplikasi terdownload, install aplikasi

c. Jika ada peringatan, maka pilih setelan dan izinkan pemasangan aplikasi

d. Kemudian install aplikasi dan aplikasi siap untuk digunakan

Data hasil validasi media pembelajaran komik berbasis android diperoleh dari pakar media sekaligus pakar materi SPLDV. Data yang diperoleh adalah data kuantitatif dan kualitatif. Data kuantitatif berupa angket yang berisi pertanyaan terhadap penilaian media pembelajaran, sedangkan data kualitatif berupa tanggapan kritik dan saran terhadap media pembelajaran yang dikembangkan. Data kuantitatif dianalasis dari perhitungan nilai rata-rata angket yang berupa skala penilaian 1, 2, 3, 4 . Nilai yang diperoleh dirujukan pada interval tingkat kevalidan terhadap media pembelajaran yang dikembangkan. Data kualitatif bisa digunakan sebagai bahan untuk melakukan perbaikan media pembelajaran yang dikembangkan.

Berdasarkan penelitian yang sudah dilakukan, media pembelajaran komik berbasis android pada materi SPLDV yang dikembangkan layak dan valid untuk digunakan dan diterapkan pada proses pembelajaran dengan skor ratarata dari validator adalah 3,43 yang termasuk kategori sangat valid. Kemudian hasil uji coba kepada praktisi (guru matematika) menunjukkan bahwa media pembelajaran praktis dan efektif 
digunakan oleh guru dan siswa dengan skor rata-rata dari praktisi adalah 3,42 yang termasuk kategori sangat praktis.

Hasil uji coba kepada 35 siswa menunjukkan bahwa media pembelajaran efektif digunakan oleh siswa dan bisa meningkatkan hasil belajar siswa. Hasil tersebut yang dibuktikan dengan skor rata-rata dari respons siswa adalah 3,17 yang termasuk kategori setuju dan skor rata-rata dari tes hasil belajar siswa adalah 74,7 dengan KKM 70. Beberapa tanggapan siswa sangat tertarik dan berminat untuk menggunakan media pembelajaran ini dikarenakan media pembelajaran ini lebih menarik dan mudah digunakan terutama pada saat pandemi seperti sekarang. Dapat disimpulkan bahwa media pembelajaran memenuhi kriteria penilaian menurut Nieveen (1999) yaitu valid, praktis dan efektif.

Kelebihan dari media pembelajaran komik berbasis android sebagai berikut:

a. Media pembelajaran yang dikembangkan memberi wawasan beru pada siswa terkait materi SPLDV pada kehidupan sehari-hari.

b. Media pembelajaran materi SPLDV membuat pembelajaran semakin menarik karena jarang ditemukan media pembelajaran komik berbasis android.

c. Media pembelajaran komik yang disusun terdiri dari 2 subbab pemahaman konsep sebelum mempelajari SPLDV dan 3 subbab metode menyelesaikan soal SPLDV yang berkaitan dengan kehidupan sehari-hari.

d. Media pembelajaran efektif digunakan oleh siapapun, dimanapun dan kapanpun.
Kekurangan dari media pembelajaran komik berbasis android sebagai berikut:

a. Ukuran media pembelajaran komik dianggap terlalu besar.

b. Media pembelajaran belum support dengan audio.

\section{SIMPULAN}

Penelitian yang dilakukan adalah penelitian pengembangan dengan melakukan 10 tahap pengembangan. Tahapan pengembangan pada penelitian ini meliputi Potensi dan Masalah, Pengumpulan Data, Desain Produk, Validasi Desain, Revisi Desain, Uji Coba Produk, Revisi Produk, Uji Coba Pemakaian, Revisi Produk, Produksi. Penelitian ini menghasilkan produk yaitu aplikasi media pembelajaran komik berbasis android materi SPLDV untuk siswa kelas VIII. Hasil penilaian penelitian, kevalidan produk termasuk kategori sangat valid dengan skor ratarata 3,43. Pada kepraktisan produk termasuk kategori sangat praktis dengan skor rata-rata 3,42. Pada keefektifan produk termasuk kategori setuju dengan skor rata-rata respons siswa 3,17 dan skor rata-rata tes hasil belajar dari 35 siswa adalah 74,7 dengan KKM 70.

\section{DAFTAR PUSTAKA}

Andre Kurniawan Pamoedji, M. R. (2017). Mudah Membuat Game Augmented Reality (AR) dan Virtual Reality (VR) dengan Unity 3D. Jakarta: PT. Elex Media Komputindo.

Arsyad, A. (2011). Media Pendidikan. Jakarta: PT. Raja Grafindo Persada.

Hidayah, S. (2016). Analisis Kesalahan Siswa dalam Menyelesaikan Soal Cerita SPLDV Berdasarkan Langkah Penyelesaian Polya. Jurnal Pendidikan 1(2). 
Iqbal, M. (2003). Dipetik Februari 18, 2021, dari Mengajar Dengan Komik: www.republika.co.id

Jariah, A. (2017). Pengembangan Media Pembelajaran Berbasis Komik Pada Materi Proses Pembekuan Darah Kelas XI MA Madani Pao-Pao Gowa. Makassar: UIN Alauddin.

Jero Budi Darmayasa, A. J. (2018). Matematika Sekolah SMP. Yogyakarta: Deepublish CV Budi Utama.

Katti, S. H. (2012). Android based mobile application development and its security. International Journal of Computer Trends and Technology.

Keogh, B., \& Naylor, S. (1999). Concept Cartoons, Teaching and Learning in Science: an Evaluation. International Journal of Science Education.

Komputer, T. L. (1994). Mudah Membuat Game 3 Dimensi Menggunakan Unity. Yogyakarta: Andi.

Lauren, M. d. (2013). Rancang Bangun Aplikasi Pembelajaran Budaya Indonesia Untuk Anak Sekolah Dasar Berbasis Android. Jurnal Ilmiah Komputasi.

Lubbis, I. R., \& Jaslin, I. (2015). Pengembangan Media Pembelajaran Kimia Berbasis Android untuk Meningkatkan Motivasi Belajar dan Prestasi Kognitif Peserta Didik SMA. Jurnal Inovasi Pendidikan IPA 1(2).

Nieveen. (1999). "Design Approaches and Tools in Education and Training". Dordrect: Springer.

Polya, G. (1973). How to Solve It: A New Aspect of Mathematical Method (Second Edition). New Jersey: Princeton University Press.
Rasiman, A. S. (2014). Development of Mathematics Learning Media. Journal of Education and Research.

Riyana, R. S. (2008). Media Pembelajaran Hakikat, Pengembangan, Pemanfaatan dan Penilaian. Bandung: CV. Wacana Prima.

Rohani, A. (1997). Media Instruksional Edukatif. Jakarta: PT. Rineka Cipta.

Saputro, H. B. (2015). Pengembangan Media Komik Berbasis Pendidikan Karakter pada Pembelajaran TematikInterGratif Kelas IV SD. Jurnal Prima Edukasia.

Sugiyono. (2012). Metode Penelitian Pendidikan : Pendekatan Kuantitatif, Kualitatif, Dan $R \& D$. Bandung: Alfa Beta.

Sukmadinata, N. S. (2013). Metode Penelitian Pendidikan. Bandung: PT. Remaja Rosdakarya.

Wahyu Nuning Budiarti, H. (2016). Pengembangan Media Komik untuk Meningkatkan Motivasi Belajar dan Keterampilan Membaca Pemahaman Siswa Kelas IV. Jurnal Prima Edukasia Volume 4, No. 2.

Wintarti, I. W. (2019). Pengembangan Media Pembelajaran M-Learning Berbasis Android Pada Materi SPLDV. Jurnal Mathedunesa Volume 8 Nomor 2. 